\title{
KAJIAN KUAT TEKAN BETON DI LINGKUNGAN LAUT TROPIS BANYUWANGI
}

\author{
Syarifah Khirunnisa ${ }^{1}$, Mirza Ghulam Rifqi ${ }^{2}$, dan M. Shofi'ul Amin ${ }^{3}$ \\ ${ }^{1}$ Jurusan Teknik Sipil, Politeknik Negeri Banyuwangi, Banyuwangi 68461 \\ E-mail : syarifahkhanis@gmail.com \\ ${ }^{2}$ Staf Pengajar Jurusan Teknik Sipil, Politeknik Negeri Banyuwangi, Banyuwangi 68461 \\ E-mail:mirza@poliwangi.ac.id \\ ${ }^{3}$ Staf Pengajar Jurusan Teknik Sipil, Politeknik Negeri Banyuwangi, Banyuwangi 68461 \\ E-mail :shofiul@poliwangi.ac.id
}

\begin{abstract}
ABSTRAK
Indonesia merupakan negara kepulauan dengan wilayah perairan yang sangat luas. Pembangunan struktur di laut merupakan hal yang tidak dapat dihindarkan. Beton digunakan karena sifatnya yang lebih tahan korosi daripada baja. Tidak dapat diabaikan bahwa beton mengalami kerusakan karena pengaruh lingkungan laut. Mehta (2003) membagi kerusakan beton di laut pada tiga zona, yakni atmospheric zone, tidal zone, dan submerged zone. Penelitian ini membahas tentang kuat tekan beton yang diletakkan di lingkungan laut tropis Banyuwangi. Menggunakan benda uji silinder beton, tipe semen PCC, FAS 0.45 dan kuat tekan rencana $35 \mathrm{MPa}$. Meski kuat tekan beton di lingkungan laut tidak mencapai kuat tekan rencana, namun di setiap umur kuat tekan beton masih mengalami peningkatan. Semakin besar kontak yang terjadi antara beton dengan air laut maka semakin besar pula penurunan kuat tekan beton yang terjadi. Kuat tekan terendah 28 hari terjadi pada beton Submerged Zone sebesar 27.16 MPa. Benda uji yang di-curing Air Tawar (BAT) pada umur 28 hari memiliki kuat tekan sebesar $35.05 \mathrm{MPa}$, benda uji Atmospheric Zone (BAZ) sebesar $32.22 \mathrm{MPa}$, benda uji Tidal Zone (BTZ) sebesar $29.80 \mathrm{MPa}$ dan benda uji Submerged Zone (BSZ) sebesar 27.16 MPa. Sampel dengan nilai kuat tekan terkecil terdapat pada Submerged Zone pada saat umur 28 hari.
\end{abstract}

Kata Kunci:

beton, kuat tekan, laut Banyuwangi

\section{PENDAHULUAN}

Pembangunan di wilayah perairan khususnya laut, memerlukan bahan bangunan yang tahan terhadap air laut yang bersifat agresif. Beton menjadi pilihan yang tepat untuk digunakan di wilayah laut dibandingkan dengan baja yang dapat mengalami korosi. Akan tetapi, tidak dapat diabaikan bahwa beton dapat mengalami kerusakan akibat adanya pengaruh lingkungan laut.

Air laut sendiri memiliki kandungan garam yang tinggi yang dapat mengurangi kekuatan dan keawetan beton. Umumnya air laut mengandung garam-garam laut $\pm 3.5 \%$ dari beratnya. Konsentrasi ion $\mathrm{Na}^{+}$dan $\mathrm{Cl}^{-}$sekitar 11000 dan $20000 \mathrm{mg} / \mathrm{l}$, sedangkan ion $\mathrm{Mg}^{+2}$ dan $\mathrm{SO}_{4}^{-2}$ kurang lebih 1400 dan $2700 \mathrm{mg} / \mathrm{l}$. Air laut mempunyai pH 7.5-8.4. Kerusakan dapat terjadi pada beton akibat reaksi antara air laut yang agresif yang masuk ke dalam beton dengan senyawa-senyawa di dalam beton yang mengakibatkan beton kehilangan sebagian massa, kehilangan kekuatan dan kekakuannya serta mempercepat proses pelapukan [6].

Kerusakan yang dialami beton akan mengakibatkan kerugian, terutama beton yang digunakan dalam infrastruktur laut misalnya pelabuhan. Kerusakan akan mengakibatkan turunnya kekuatan struktur dan memperpendek masa layan bangunan. Jika dibiarkan dan kerusakan yang terjadi semakin parah, maka bangunan tidak dapat dipergunakan kembali.
Di Indonesia sendiri penelitian mengenai pengaruh air laut terhadap beton telah dilakukan. Penggunaan air laut sebagai media perawatan (curing) dengan variasi faktor air semen memberikan perbedaan pengaruh terhadap kuat tekan beton. Kuat tekan beton yang menggunakan air bersih lebih tinggi dibandingkan yang menggunakan air laut [7]. Pada beton mutu K-175 yang menggunakan air laut sebagai media perawatan maupun bahan campuran juga menunjukkan nilai kuat tekan yang lebih rendah jika dibandingkan dengan beton yang menggunakan air tawar [2]. Dalam penelitian lain, penggunaan air laut sebagai media perawatan beton menunjukkan bahwa beton yang mengalami perawatan dengan air laut memiliki kuat tekan awal yang lebih tinggi dari pada beton yang mengalami perawatan dengan air tawar, namun setelah itu kekuatannya akan lebih rendah [10]. Pada daerah pasang surut penggunaan air laut sebagai air pencampur beton menunjukkan beton dengan curing basah memiliki nilai kuat tekan yang lebih tinggi dibandingkan beton dengan curing kering-basah (daerah pasang surut) [1]. Intrusi air laut juga memiliki pengaruh terhadap kuat tekan beton. Beton yang mengalami intrusi air laut menunjukkan nilai kuat tekan yang lebih rendah dibandingkan dengan beton yang terintrusi air gambut, air kelapa maupun air biasa [3]. Melihat pengaruh air laut yang signifikan pada beton, maka perlu dilakukan penelitian mengenai pengaruh air laut terhadap beton dengan mempertimbangkan bidang kontak beton dengan air laut. 


\section{TINJAUAN PUSTAKA}

Tingkat kerusakan yang dialami beton berbeda-beda tergantung dari kondisi paparan atau bidang kontak beton dengan air laut. Tiga kondisi kerusakan beton akibat pengaruh air laut diilustrasikan pada Gambar 1.

\section{Submerged zone}

Submerged zone adalah bagian dari struktur yang selalu dan terus-menerus terendam air laut. Laju korosi karena kandungan klorida dalam air laut tergantung pada ketersediaan oksigen. Korosi tulangan jarang terjadi pada bagian ini karena kekurangan oksigen.

2. Tidal zone

Tidal zone adalah bagian dari struktur yang mengalami kondisi kering-basah berulang-ulang oleh air lut. Pada zona ini gelombang mencapai level air tertinggi dan terendah, beton mengalami semua jenis serangan baik fisik maupun kimia, dan tulangan rentan terhadap korosi karena adanya kombinasi antara kelembaban, garam dan oksigen. Pada kondisi ini juga terjadi kerusakan karena kristalisasi garam. Di Negara yang memiliki empat jenis musim maka pada tidal zone akan terjadi kerusakan akibat proses pembekuan dan pencairan air laut.

3. Atmospheric zone

Atmospheric zone adalah bagian dari struktur yang berada di atas tidal zone. Kerusakan yang terjadi pada bagian ini menyerupai dengan kerusakan yang terjadi pada tidal zone tetapi dalam tingkatan yang lebih rendah. Abrasi akibat gelombang dan benda mengambang tidak akan terjadi pada zona ini.

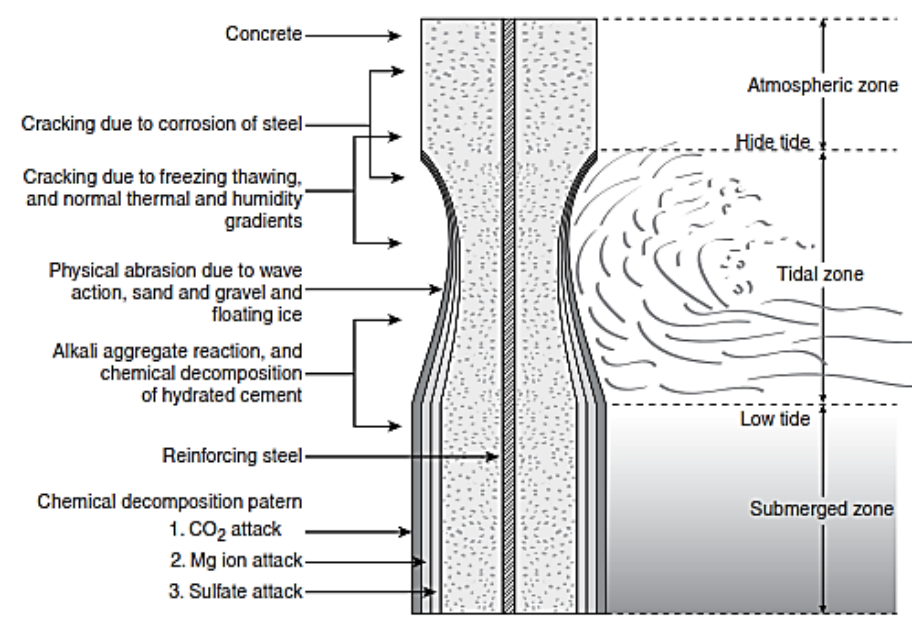

Gambar 1. Skema perusakan beton akibat air laut [6]

Marine growth yang tumbuh pada permukaan beton tidak hanya berupa alga namun juga barnacle yang dalam Bahasa Indonesia dikenal sebagai "teritip". Ciri-ciri teritip adalah seluruh tubuhnya diselubungi oleh cangkang. Pada teritip dewasa, cangkang tersebut terbentuk dari zat kapur. Teritip memiliki kelenjar penghasil "cement" dan "antenula" yang berguna untuk mengikatkan tubuh ke suatu substrat saat dimulainya stadium dewasa [4].

Perhitungan standar deviasi dilakukan untuk mencari keseragaman benda uji yang dihasilkan. Semakin kecil nilai standar deviasi maka benda uji yang dibuat semakin seragam. Klasifikasi standar deviasi mengacu pada SNI $03-$ 6815-2002 tentang Tata Cara Mengevaluasi Hasil Uji Kekuatan Beton yang membagi standar deviasi ke dalam lima kategori, yakni kurang, cukup, baik, sangat baik dan terbaik [9].

\section{URAIAN PENELITIAN}

\subsection{Karakteristik Material}

Material campuran beton terdiri dari air, semen portland komposit, pasir Lumajang sebagai agregat halus dan batu pecah sebagai agregat kasar. Pengujian material campuran beton dilakukan di Laboratorium Uji Beton Teknik Sipil Politeknik Negeri Banyuwangi. Karakteristik fisik agregat yang digunakan dapat dilihat pada Tabel 1.

Tabel 1. Karakteristik fisik agregat yang digunakan

\begin{tabular}{lcc}
\hline Karakteristik fisik agregat & Kasar & Halus \\
\hline Ukuran maksimum $(\mathrm{mm})$ & 20 & 2.9 \\
Berat jenis & 2.53 & 2.56 \\
Kadar air resapan $(\%)$ & & \\
Asli & 0.1 & 1.40 \\
$\mathrm{SSD}$ & 1.70 & 1.56 \\
Berat volume $\left(\mathrm{kg} / \mathrm{m}^{3}\right)$ & & \\
Rojokan & 1455.56 & 1553.71 \\
Tanpa rojokan & 1404.44 & 1387.36 \\
Angka kehalusan & 6.64 & 2.91 \\
\hline
\end{tabular}

\subsection{Mix Design}

Proporsi campuran dibuat berdasarkan metode Development of Environtment (DOE) dengan mengacu pada SNI 03-2834-2000 [8]. Berikut adalah prosedur Mix Design yang digunakan dalam penelitian ini :

1. Kuat tekan rencana

$$
\begin{aligned}
& =35 \mathrm{MPa} \\
& =35 \mathrm{MPa} \\
& =0.45 \text { (ditetapkan) } \\
& =12 \pm 2 \\
& =225 \mathrm{~kg} / \mathrm{m}^{3} \\
& =500 \mathrm{~kg} / \mathrm{m}^{3} \\
& =Z \mathrm{Zona} 2 \\
& =40 \% \\
& =2.544 \\
& =2281.25 \mathrm{~kg} / \mathrm{m}^{3} \\
& =1556.25 \mathrm{~kg} / \mathrm{m}^{3} \\
& =622.5 \mathrm{~kg} / \mathrm{m}^{3} \\
& =933.75 \mathrm{~kg} / \mathrm{m}^{3}
\end{aligned}
$$$$
\text { Kuat tekan target akibat koreksi }
$$$$
\text { standar deviasi sebesar } 0 \mathrm{MPa}=35 \mathrm{MPa}
$$$$
\text { 2. Faktor air semen } \quad=0.45 \text { (ditetapkan) }
$$$$
\text { 3. Slump }
$$$$
\text { 4. Kadar air bebas }
$$$$
\text { 5. Jumlah semen }
$$$$
\text { 6. Gradasi agregat halus }
$$$$
\text { 7. Persen agregat halus }
$$$$
\text { 8. Berat jenis relatif (SSD) }
$$$$
\text { 9. Berat isi beton }
$$$$
\text { 10. Kadar agregat gabungan }
$$$$
\text { 11. Kadar agregat halus }
$$$$
\text { 12. Kadar agregat kasar }
$$

\subsection{Pembuatan Benda Uji}

Tabel 2. Jumlah benda uji

\begin{tabular}{ccccc}
\hline \multirow{2}{*}{$\begin{array}{c}\text { Kode } \\
\text { Benda Uji }\end{array}$} & \multicolumn{3}{c}{ Jumlah Kuat Tekan Silinder } & \\
\cline { 2 - 4 } & \multicolumn{3}{c}{ Umur } & \\
\cline { 2 - 4 } & 7 & 14 & 28 & \\
\hline BAT & 3 & 3 & 3 & 9 \\
BAZ & 3 & 3 & 3 & 9 \\
BTZ & 3 & 3 & 3 & 9 \\
BSZ & 3 & 3 & 3 & 9 \\
\hline Total & & & 36 \\
\hline
\end{tabular}


Keterangan :

BAT = Beton curing Air Tawar

BAZ = Beton diletakkan di Atmospheric Zone

BTZ = Beton diletakkan di Tidal Zone

BSZ = Beton diletakkan di Submerged Zone

Benda uji yang dibuat adalah silinder beton berdiameter 15 $\mathrm{cm}$ dan tinggi $30 \mathrm{~cm}$. Jumlah benda uji dapat dilihat pada Tabel 2 dan Proses pembuatan benda uji ditunjukkan pada Gambar 2 dan Gambar 3.

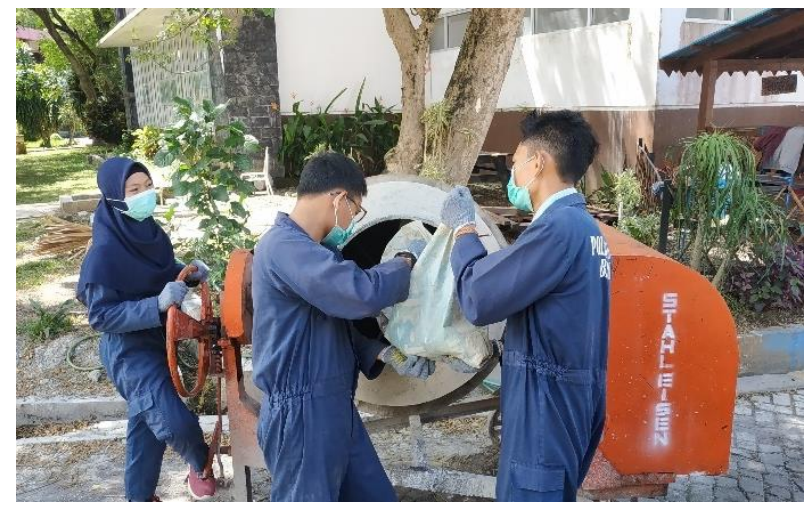

Gambar 2. Proses pencampuran material beton

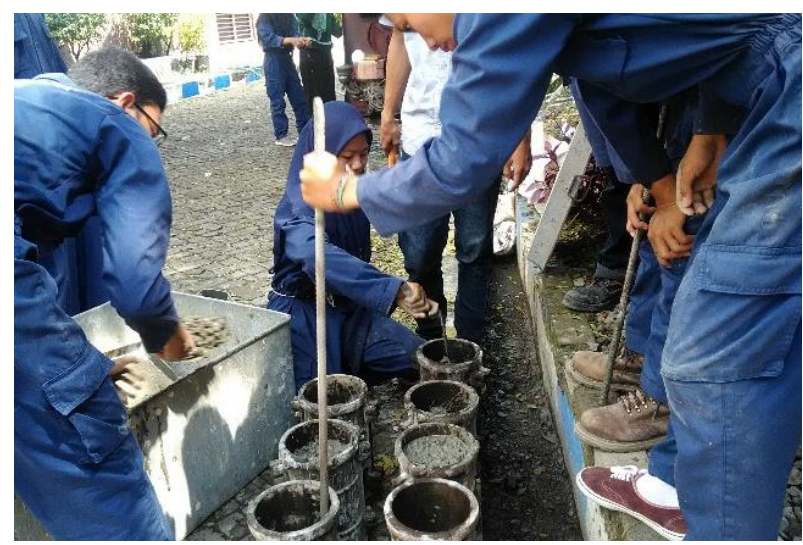

Gambar 3. Proses pencetakan benda uji beton

\subsection{Peletakan Benda Uji di Lingkungan Laut}

Agar dapat diketahui pengaruh lingkungan laut tropis Banyuwangi pada beton, maka dibuat benda uji yang dirawat dengan cara curing air tawar (BAT) sebagai pembanding nilai kuat tekan.

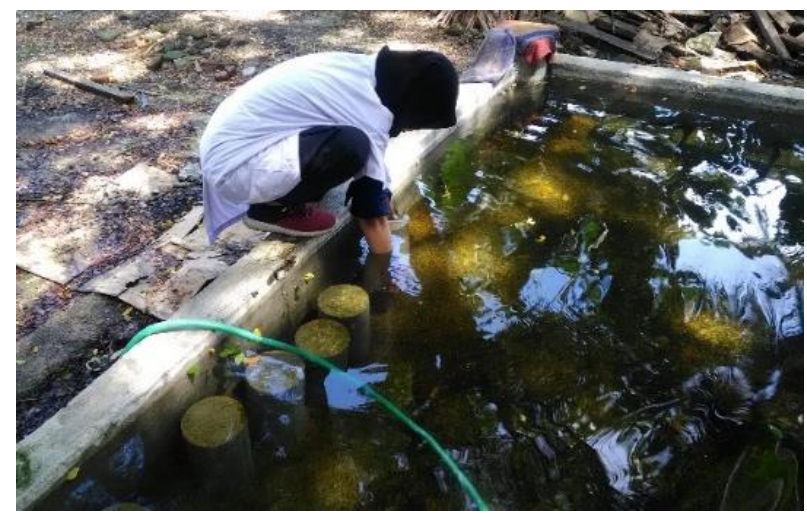

Gambar 4. Proses curing pada benda uji beton
Perawatan curing beton dilakukan di Laboratorium Uji Beton Teknik Sipil Politeknik Negeri Banyuwangi seperti yang terlihat pada Gambar 4. Benda uji curing air tawar diuji tekan ketika mencapai umur 7, 14 dan 28 hari.

Benda uji BAZ, BTZ dan BSZ di letakkan di area wisata Rumah Apung Bangsring Underwater yang mewakili laut sisi timur Kabupaten Banyuwangi. Beton diletakkan pada saat beton berumur 6 hari. Hal ini dikarenakan benda uji beton tidak boleh berkontak langsung dengan air laut hingga mencapai umur 5 hari [5]. Sebelum mencapai umur 5 hari, beton diletakkan dalam suhu ruang di Laboratorium Uji Beton Teknik Sipil Politeknik Negeri Banyuwangi. Ilustrasi peletakan benda uji di lingkungan laut disajikan pada Gambar 5.

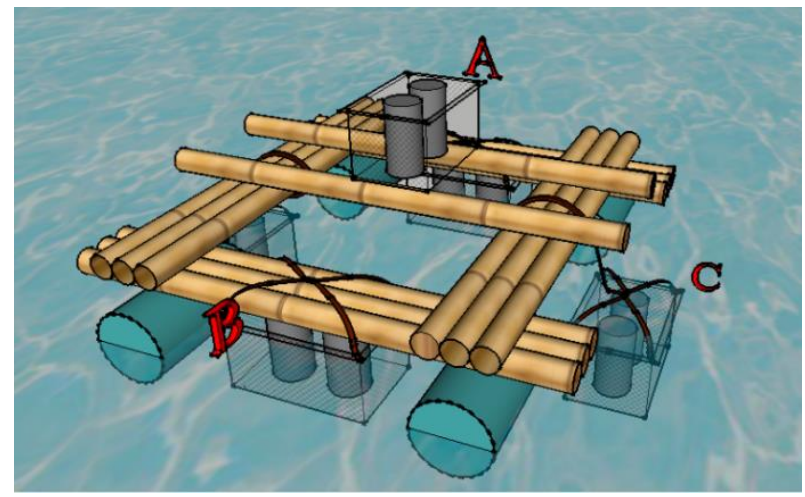

Gambar 5. Ilustrasi peletakan benda uji di lingkungan laut

Keterangan:

$\mathrm{A}=$ Atmospheric Zone

$\mathrm{B}=$ Tidal Zone

$\mathrm{C}=$ Submerged Zone

Dalam pelaksanaannya, benda uji di atmospheric zone diletakkan pada keranjang plastik yang sisi-sisinya memiliki lubang, hal ini dilakukan agar ketika air laut mengalami penguapan, benda uji tidak terhalang oleh sisisisi keranjang. Sedangkan untuk benda uji di tidal zone dan submerged zone dimasukkan ke dalam keranjang jaring yang terbuat dari tali tambang plastik, kemudian diikat pada keramba apung. Peletakan benda uji di lingkungan laut dapat dilihat pada Gambar 6 sampai dengan Gambar 8.

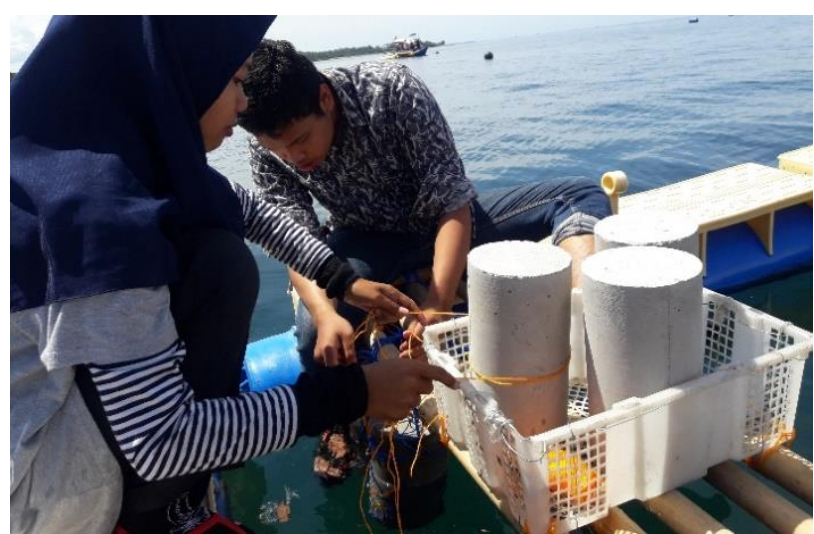

Gambar 6. Peletakan benda uji di atmospheric zone 


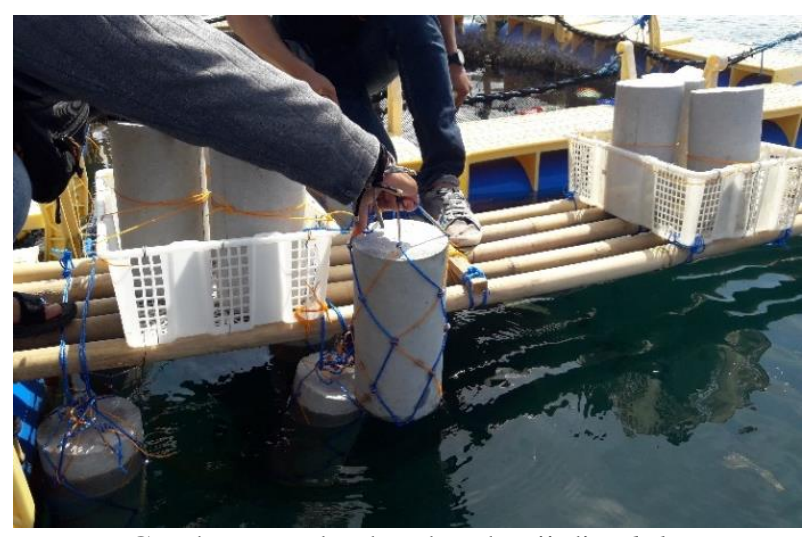

Gambar 7. Peletakan benda uji di tidal zone

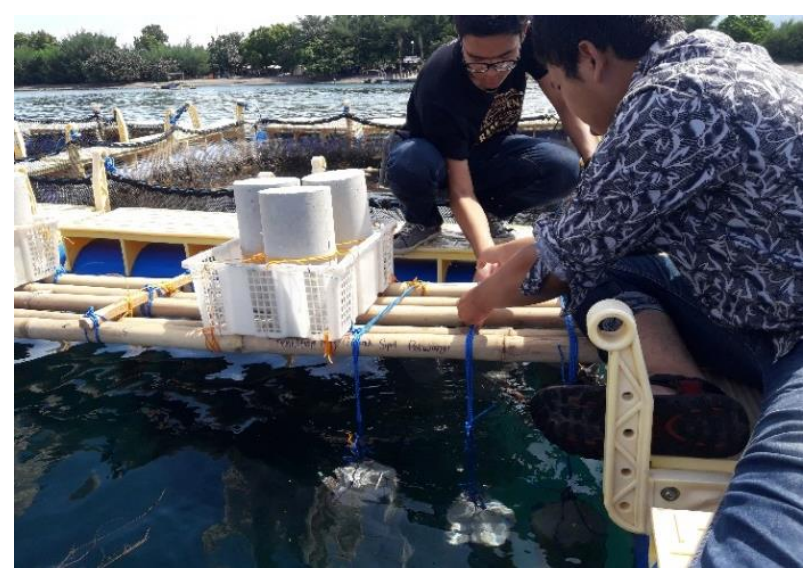

Gambar 8. Peletakan benda uji di submerged zone

Sama seperti benda uji BAT, benda uji BAZ, BTZ dan BSZ diuji kuat tekan pada umur 7, 14 dan 28 hari. Dimana benda uji umur 7 hari telah berada di lingkungan laut selama 24 jam, benda uji umur 14 hari selama 192 jam dan benda uji umur 28 hari selama 528 jam.

\section{HASIL DAN PEMBAHASAN}

Setelah mencapai umur pengujian benda uji dipindahkan dari lingkungan laut ke laboratorium, untuk selanjutnya dilakukan pengujian kuat tekan. Kondisi benda uji setelah diletakkan di lingkungan laut dapat dilihat pada Gambar 9 sampai dengan Gambar 11.

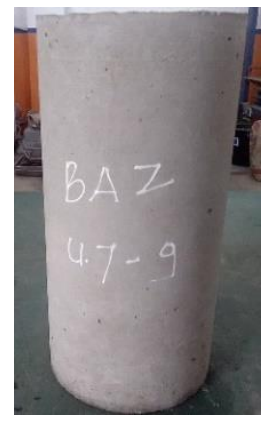

(a)

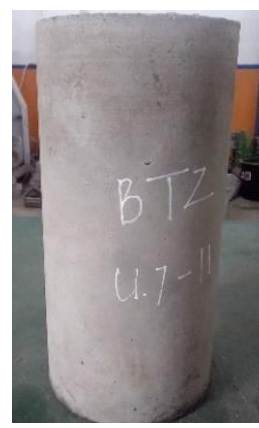

(b)

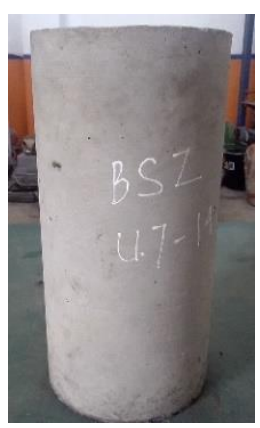

(c)
Gambar 9. Kondisi benda uji umur 7 hari (a) atmospheric zone (b) tidal zone (c) submerged zone

Benda uji umur 7 hari yang telah berada di lingkungan laut selama 24 jam tidak banyak mengalami perubahan pada kondisi fisik permukaan beton. Terlihat pada Gambar 9, bahwa baik benda uji yang mengalami kontak langsung dengan air laut maupun yang tidak mengalami kontak langsung dengan air laut, tiap-tiap benda uji memiliki penampilan luar yang sama, yakni berwarna abu-abu terang.

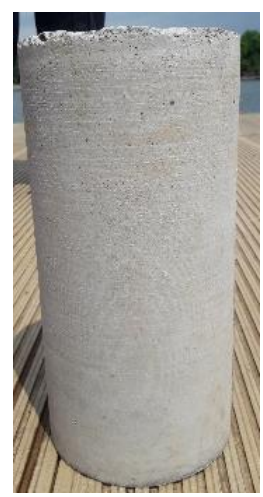

(a)

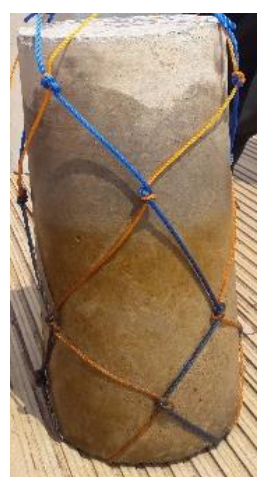

(b)

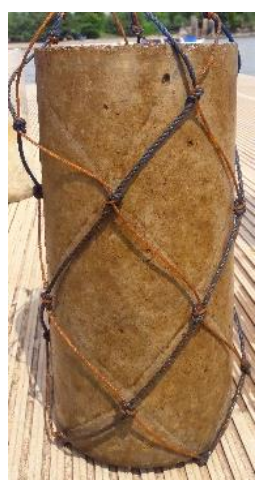

(c)
Gambar 10. Kondisi benda uji umur 14 hari (a) atmospheric zone (b) tidal zone (c) submerged zone

Pada benda uji yang telah berada di lingkungan laut selama 192 jam terlihat perbedaan penampakan permukaan beton. Benda uji atmospheric zone memiliki warna abu-abu terang pada permukaannya. Benda uji tidal zone memiliki 3 warna pada permukaannya, yakni abu-abu terang, abu-abu gelap dan coklat kehijauan.

Abu-abu terang menunjukkan bagian yang tidak terkena air laut, abu-abu gelap menunjukkan bagian yang secara berkala terkena air laut dan warna coklat kehijauan menunjukkan bagian yang selalu terendam oleh air laut. Warna coklat kehijauan terjadi karena pada permukaan beton tumbuh marine growth berupa alga. Pada benda uji submerged zone seluruh permukaannya memiliki warna coklat kehijauan. Sama seperti bagian benda uji tidal zone yang terus terendam air laut, permukaan benda uji submerged zone ditumbuhi oleh marine growth berupa alga.

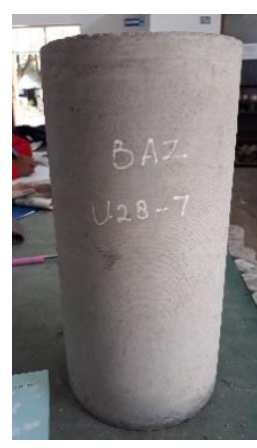

(a)

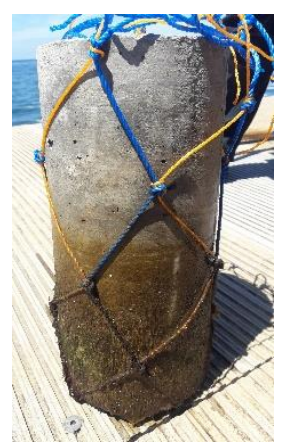

(b)

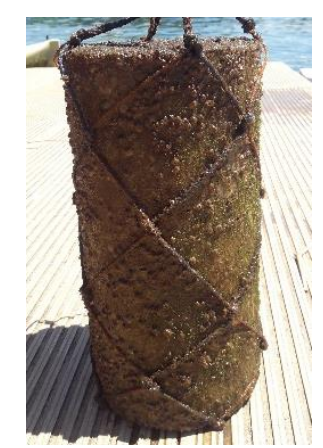

(c)
Gambar 11. Kondisi benda uji umur 28 hari (a) atmospheric zone (b) tidal zone (c) submerged zone

Benda uji umur 28 hari yang telah berada di lingkungan laut selama 528 jam memiliki penampilan yang paling banyak mengalami perubahan, kecuali pada benda uji atmospheric zone masih sama dengan warna abu-abu terang karena tidak mengalami kontak langsung dengan air laut. 
Marine growth yang tumbuh pada permukaan beton umur 28 hari, tidak hanya berupa alga namun juga barnacle yang dalam Bahasa Indonesia dikenal sebagai "teritip". Barnacle yang tumbuh pada permukaan beton dapat dilihat pada Gambar 12.

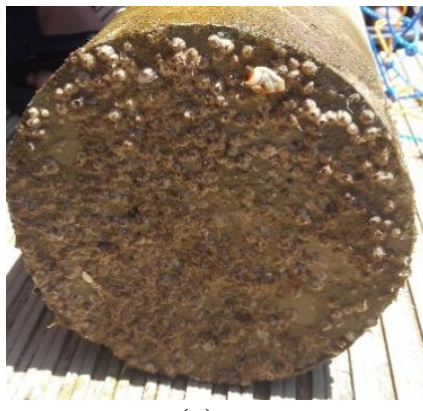

(a)

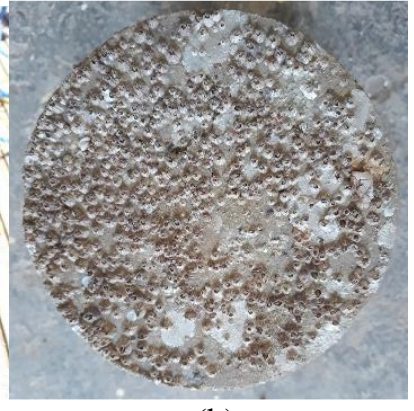

(b)
Gambar 12. Barnacle pada permukaan beton (a) kondisi basah (b) kondisi kering

\subsection{Berat Volume Beton}

Sebelum proses uji kuat tekan, dilakukan pemeriksaan berat volume pada beton. Pemeriksaan berat volume dilakukan dengan cara menimbang masing-masing benda uji. Hasil pengujian berat volume rata-rata dapat dilihat pada Tabel 3.

Tabel 3. Berat volume rata-rata beton

\begin{tabular}{cccc}
\hline $\begin{array}{c}\text { Kode } \\
\text { benda } \\
\text { uji }\end{array}$ & $\begin{array}{c}\text { Berat volume } \\
\text { rata-rata umur } \\
7 \text { hari }\left(\mathrm{kg} / \mathrm{m}^{3}\right)\end{array}$ & $\begin{array}{c}\text { Berat volume } \\
\text { rata-rata umur } \\
14 \text { hari }\left(\mathrm{kg} / \mathrm{m}^{3}\right)\end{array}$ & $\begin{array}{c}\text { Berat volume } \\
\text { rata-rata umur } \\
28 \text { hari }\left(\mathrm{kg} / \mathrm{m}^{3}\right)\end{array}$ \\
\hline BAT & 2247.91 & 2249.36 & 2227.73 \\
BAZ & 2234.08 & 2222.60 & 2187.27 \\
BTZ & 2255.55 & 2267.69 & 2209.53 \\
BSZ & 2255.02 & 2261.62 & 2230.84 \\
\hline
\end{tabular}

Lingkungan laut berpengaruh pada berat volume benda uji. Benda uji yang mengalami kontak langsung dengan air laut memiliki berat volume yang lebih besar dibandingkan dengan benda uji yang tidak berkontak langsung dengan air laut. Namun jika dibandingkan dengan benda uji curing air tawar, berat volume benda uji curing air laut memiliki nilai berat volume yang lebih besar.

\subsection{Uji Kuat Tekan}

Uji kuat tekan dilakukan pada silinder beton dengan diameter $15 \mathrm{~cm}$ dengan tinggi $30 \mathrm{~cm}$. Pengujian dilaksanakan di Laboratorium Uji Beton Teknik Sipil Politeknik Negeri Banyuwangi. Hasil kuat tekan dapat dilihat pada Tabel 4 dan Gambar 13 sampai dengan Gambar 15 .

\begin{tabular}{|c|c|c|c|}
\hline $\begin{array}{c}\text { Kode } \\
\text { benda } \\
\text { uji } \\
\end{array}$ & $\begin{array}{l}\text { Kuat tekan } \\
\text { rata-rata } 7 \\
\text { hari }(\mathrm{MPa}) \\
\end{array}$ & $\begin{array}{l}\text { Kuat tekan } \\
\text { rata-rata14 } \\
\text { hari (MPa) } \\
\end{array}$ & $\begin{array}{c}\text { Kuat tekan rata- } \\
\text { rata } 28 \text { hari } \\
(\mathrm{MPa})\end{array}$ \\
\hline BAT & 25.84 & 32.82 & 35.05 \\
\hline $\mathrm{BAZ}$ & 24.82 & 25.80 & 32.22 \\
\hline BTZ & 23.01 & 24.67 & 29.80 \\
\hline BSZ & 22.71 & 24.97 & 27.16 \\
\hline
\end{tabular}

Pada umur 7 hari benda uji yang telah berada selama 24 jam di lingkungan laut memiliki nilai kuat tekan yang lebih rendah dibandingkan dengan benda uji curing air tawar. Dengan urutan kuat tekan dari yang terbesar ke yang terkecil adalah benda uji BAT (25.84 MPa), benda uji BAZ (24.82 MPa), benda uji BTZ (23.01 MPa), dan yang terakhir benda uji BSZ (22.71 MPa).

Benda uji BAZ memiliki nilai kuat tekan yang lebih tinggi dibandingkan dengan benda uji BTZ dan BSZ dan perbedaan hasil uji kuat tekan menunjukkan penurunan nilai kuat tekan yang signifikan. Hal ini dimungkinkan dapat terjadi dikarenakan adanya intrusi air laut pada beton. Kondisi tersebut ditunjukkan pada Gambar 13.

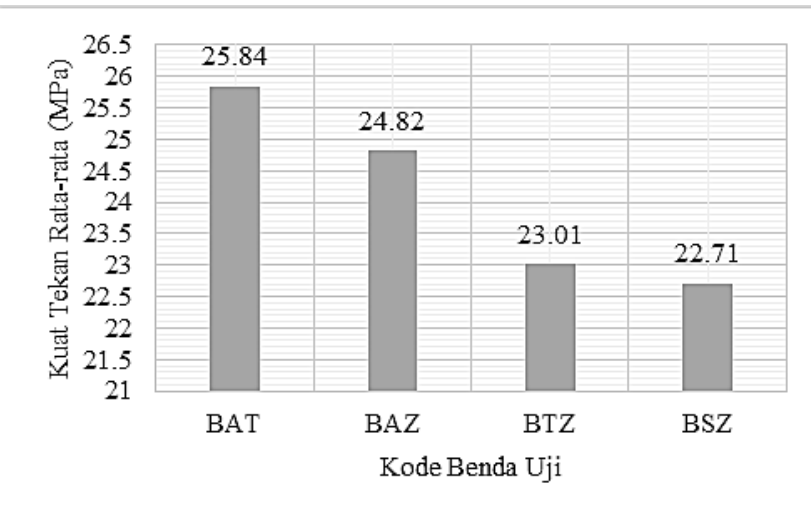

Gambar 13. Kuat tekan rata-rata umur 7 hari

Pada pengujian umur 14 hari urutan kuat tekan dari yang terbesar ke yang terkecil adalah benda uji BAT (32.82 $\mathrm{MPa})$, benda Uji BAZ (25.80 MPa), benda uji BSZ (24.97 $\mathrm{MPa})$, dan yang terakhir benda uji BTZ (24.67 MPa).

Sama seperti umur 7 hari, benda uji yang mengalami kontak langsung dengan air laut selama 192 jam memiliki kuat tekan yang lebih rendah dibandingkan benda uji yang tidak berkontak langsung dengan air laut. Hasil uji tekan pada sampel beton umur 14 hari untuk BAZ, BTZ dan BSZ, menunjukkan mutu yang tidak berbeda jauh. Namun mutunya jauh lebih rendah dibandingkan dengan sampel BAT. Perilaku benda uji pada umur 14 hari ditunjukkan pada Gambar 14.

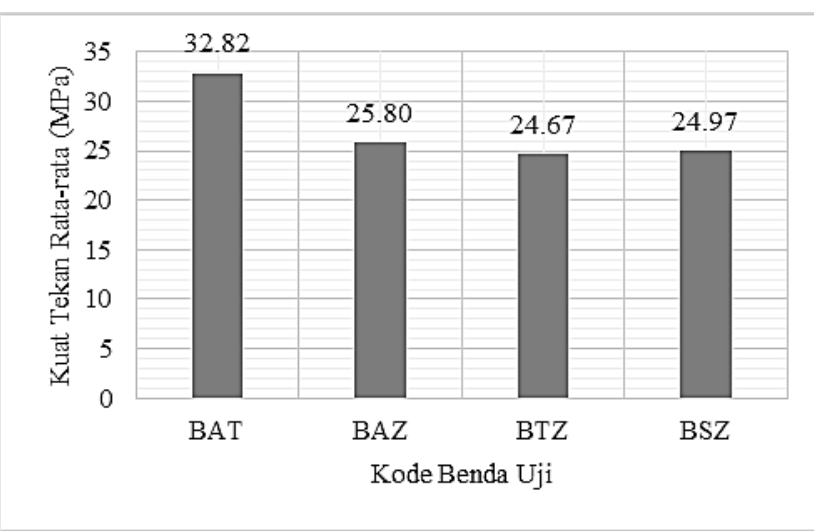

Gambar 14. Kuat tekan rata-rata umur 14 hari

Pada pengujian umur 28 hari urutan kuat tekan dari yang 
terbesar ke yang terkecil adalah benda uji BAT (35.05 $\mathrm{MPa})$, benda uji BAZ (32.22 MPa), benda uji BTZ (29.80 $\mathrm{MPa})$, dan yang terakhir benda uji BSZ (27.16 MPa).

Sama seperti dua umur pengujian sebelumnya, benda uji yang mengalami kontak langsung dengan air laut selama 528 jam memiliki kuat tekan yang lebih rendah dibandingkan benda uji yang tidak berkontak langsung dengan air laut. Perbedaan mutu beton untuk BAT, BAZ, BTZ dan BSZ rata-rata memiliki nilai yang seragam yaitu sekitar 3 MPa. Mutu benda uji untuk umur 28 hari ditunjukkan pada Gambar 15.

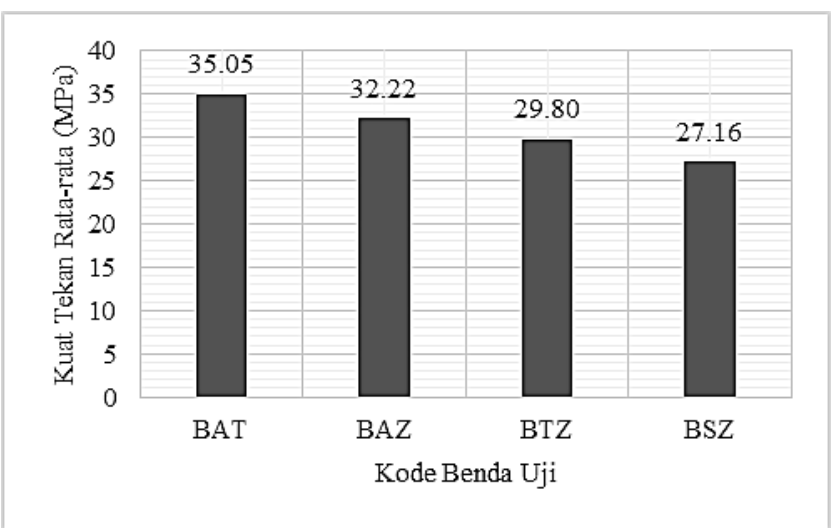

Gambar 15. Kuat tekan rata-rata umur 28 hari

Hasil pengujian pada umur 7, 14 dan 28 hari menunjukkan bahwa setiap benda uji yang diletakkan di lingkungan laut mengalami peningkatan kuat tekan di setiap umur pengujian. Dari ketiga kondisi kontak beton dengan air laut, atmospheric zone memiliki nilai kuat tekan paling tinggi di setiap pengujian.

Hasil kuat tekan dengan adanya perbedaan kondisi peletakan menunjukkan terjadinya penurunan mutu beton dibandingkan dengan beton yang dirawat menggunakan air tawar. Hasil pengujian kuat tekan benda uji BAZ dengan benda uji BAT sebagai acuan mengalami penurunan sebesar $4 \%$ (umur 7 hari), 21\% (umur 14 hari), dan $8 \%$ (umur 28 hari) ditunjukkan pada Gambar 16.

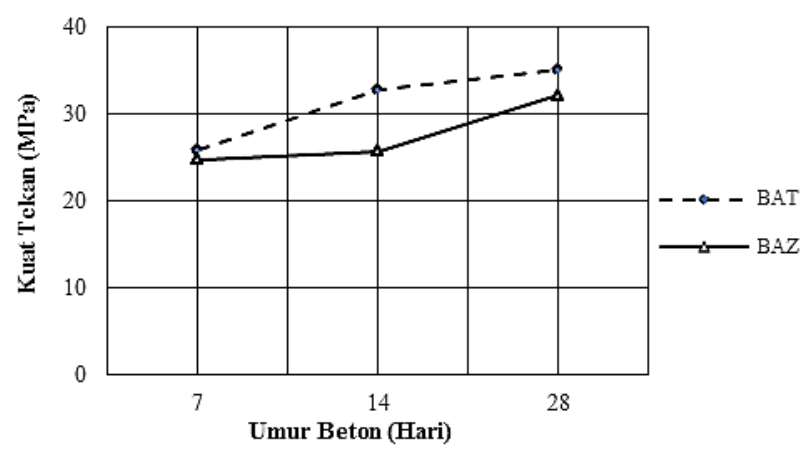

Gambar 16. Penurunan mutu BAZ terhadap mutu BAT

Hasil pengujian kuat tekan benda uji BTZ, seperti yang ditampilkan pada Gambar 17, dengan benda uji BAT sebagai acuan mengalami penurunan sebesar $11 \%$ (umur 7 hari), $25 \%$ (umur 14 hari), dan $15 \%$ (umur 28 hari).
Hasil pengujian kuat tekan benda uji BSZ dengan benda uji BAT sebagai acuan mengalami penurunan sebesar $12 \%$ (umur 7 hari), 24\% (umur 14 hari), dan 23\% (umur 28 hari). Penurunan benda uji BSZ dapat dilihat pada Gambar 18.

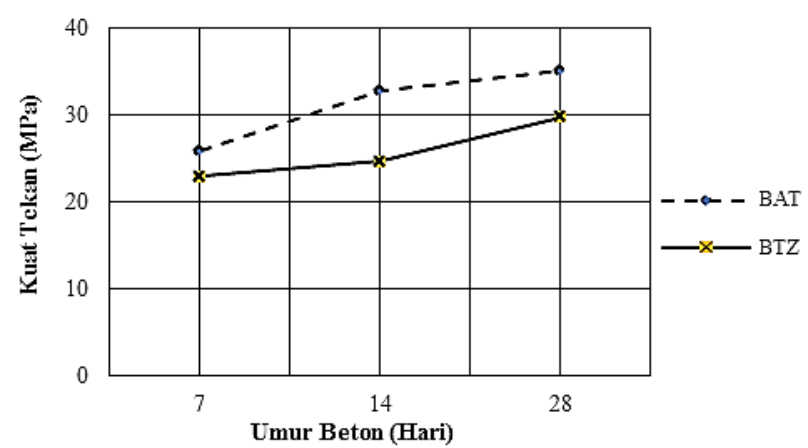

Gambar 17. Penurunan mutu BTZ terhadap mutu BAT

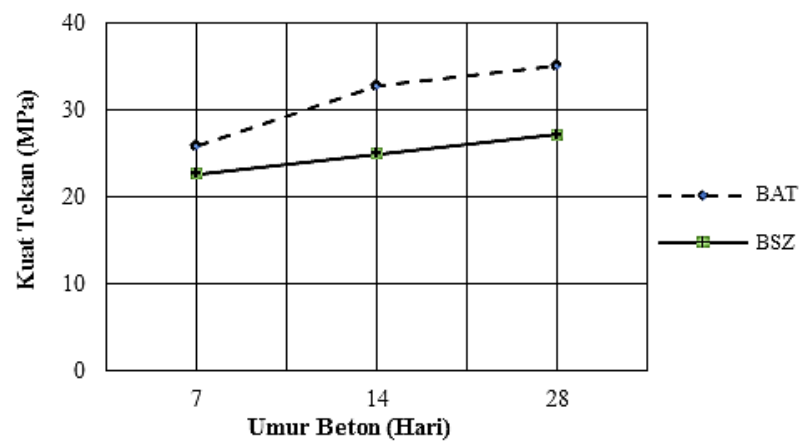

Gambar 18. Penurunan mutu BAZ terhadap mutu BAT

\subsection{Standar Deviasi}

Perhitungan standar deviasi dilakukan untuk mencari keseragaman benda uji yang dihasilkan. Semakin kecil nilai standar deviasi maka benda uji yang dibuat semakin seragam. Nilai standar deviasi kuat tekan umur 7, 14 dan 28 hari rata-rata masuk ke dalam kategori terbaik. Di mana kategori ini menunjukkan bahwa keseragaman benda uji yang dibuat cukup tinggi.

Nilai standar deviasi dapat dilihat pada Tabel 5 sampai dengan Tabel 7.

Tabel 5. Standar deviasi hasil kuat tekan umur 7 hari

\begin{tabular}{ccccc}
\hline Kode & $\begin{array}{c}\text { Kuat tekan } \\
(\mathrm{MPa})\end{array}$ & $\begin{array}{c}\text { Kuat tekan } \\
\text { rata-rata } \\
(\mathrm{MPa})\end{array}$ & $\begin{array}{c}\text { Standar } \\
\text { deviasi }\end{array}$ & $\begin{array}{c}\text { Klasifikasi } \\
\text { standar } \\
\text { deviasi }\end{array}$ \\
\hline \multirow{3}{*}{ BAT } & 26.48 & & & \\
& 24.79 & 25.84 & 0.92 & Terbaik \\
& 26.26 & & & \\
BAZ & 24.45 & & & \\
& 26.03 & 24.82 & 1.07 & Terbaik \\
& 23.99 & & & \\
BTZ & 23.77 & & & \\
& 21.73 & 23.01 & 1.12 & Terbaik \\
& 23.54 & & & \\
BSZ & 21.73 & & & \\
& 23.77 & 22.71 & 1.02 & Terbaik \\
\hline
\end{tabular}


Tabel 6. Standar deviasi hasil kuat tekan umur 14 hari

\begin{tabular}{|c|c|c|c|c|}
\hline Kode & $\begin{array}{c}\text { Kuat tekan } \\
\text { (MPa) }\end{array}$ & $\begin{array}{c}\text { Kuat tekan } \\
\text { rata-rata } \\
(\mathrm{MPa})\end{array}$ & $\begin{array}{c}\text { Standar } \\
\text { deviasi }\end{array}$ & $\begin{array}{c}\text { Klasifikasi } \\
\text { standar } \\
\text { deviasi }\end{array}$ \\
\hline \multirow{3}{*}{ BAT } & 32.37 & \multirow{3}{*}{32.82} & \multirow{4}{*}{0.45} & \multirow{3}{*}{ Terbaik } \\
\hline & 33.82 & & & \\
\hline & 32.27 & & & \\
\hline \multirow{4}{*}{ BAZ } & 24.90 & \multirow{4}{*}{25.80} & & \multirow{4}{*}{ Terbaik } \\
\hline & 25.58 & & \multirow[t]{3}{*}{1.04} & \\
\hline & 26.94 & & & \\
\hline & 23.99 & & & \\
\hline \multirow[t]{3}{*}{ BTZ } & 24.67 & \multirow[t]{3}{*}{24.67} & \multirow{3}{*}{0.68} & \multirow{3}{*}{ Terbaik } \\
\hline & 25.35 & & & \\
\hline & 24.45 & & & \\
\hline \multirow[t]{2}{*}{ BSZ } & 26.48 & \multirow[t]{2}{*}{24.97} & \multirow[t]{2}{*}{1.33} & \multirow[t]{2}{*}{ Terbaik } \\
\hline & 23.99 & & & \\
\hline
\end{tabular}

Tabel 7. Standar deviasi hasil kuat tekan umur 28 hari

\begin{tabular}{|c|c|c|c|c|}
\hline Kode & $\begin{array}{l}\text { Kuat tekan } \\
\text { (MPa) }\end{array}$ & $\begin{array}{c}\text { Kuat tekan } \\
\text { rata-rata } \\
\text { (MPa) }\end{array}$ & $\begin{array}{l}\text { Standar } \\
\text { deviasi }\end{array}$ & $\begin{array}{c}\text { Klasifikas } \\
\text { standar } \\
\text { deviasi }\end{array}$ \\
\hline \multirow{4}{*}{ BAT } & 33.84 & & \multirow{4}{*}{1.31} & \multirow{4}{*}{ Terbaik } \\
\hline & 34.86 & 35.05 & & \\
\hline & 36.44 & & & \\
\hline & 30.33 & & & \\
\hline \multirow[t]{3}{*}{ BAZ } & 32.14 & \multirow[t]{2}{*}{32.22} & \multirow[t]{3}{*}{1.93} & \multirow{3}{*}{ Terbaik } \\
\hline & 34.18 & & & \\
\hline & 28.07 & \multirow{4}{*}{29.80} & & \\
\hline \multirow{3}{*}{ BTZ } & 29.65 & & \multirow{3}{*}{1.81} & \multirow{3}{*}{ Baik } \\
\hline & 31.69 & & & \\
\hline & 27.16 & & & \\
\hline \multirow[t]{2}{*}{ BSZ } & 28.97 & \multirow[t]{2}{*}{27.16} & \multirow[t]{2}{*}{1.81} & \multirow[t]{2}{*}{ Baik } \\
\hline & 25.35 & & & \\
\hline
\end{tabular}

\section{KESIMPULAN}

Dari hasil pengujian dan analisa kuat tekan beton di lingkungan laut tropis Banyuwangi dapat disimpulkan:

1. Pada umur 7 hari, 14 hari, dan 28 hari berturut-turut benda uji yang di-curing air tawar (BAT) memiliki kuat tekan sebesar $25.84 \mathrm{MPa}$; $32.82 \mathrm{MPa}$; $35.05 \mathrm{MPa}$, benda uji di atmospheric zone (BAZ) sebesar 24.82 $\mathrm{MPa}$; $25.80 \mathrm{MPa}$; $32.22 \mathrm{MPa}$, benda uji di tidal zone (BTZ) sebesar 23.01 MPa; 24.67 MPa; 29.80 MPa, dan benda uji di submerged zone (BSZ) sebesar $22.71 \mathrm{MPa}$; 24.97 MPa; 27.16 MPa.

2. Hasil pengujian umur 7 hari, 14 hari, dan 28 hari dengan kuat tekan benda uji BAT sebagai acuan, berturut-turut benda uji BAZ 4\%, 21\%, 8\%; benda uji BTZ $11 \%$, $25 \%, 15 \%$; dan benda uji BSZ 12\%, 24\%, $23 \%$.

3. Semakin besar kontak yang terjadi antara beton dengan air laut maka semakin besar pula penurunan kuat tekan beton yang terjadi. Dalam penelitian ini submerged zone yang merupakan wilayah di mana seluruh bagian beton terendam air laut memiliki nilai kuat tekan yang paling kecil saat umur 28 hari.

\section{UCAPAN TERIMAKASIH}

Terima kasih penulis sampaikan kepada:

1. Direktorat Pendidikan Tinggi, Departemen Pendidikan dan Kebudayaan Republik Indonesia yang telah memberikan dukungan finansial melalui Beasiswa Bidik Misi tahun 2016-2019.
2. Pengurus area wisata Bangsring Underwater yang telah memberikan ijin tempat serta fasilitas selama penelitian dilaksanakan.

3. Politeknik Negeri Banyuwangi yang telah memfasilitasi pengujian dan perawatan material uji.

\section{DAFTAR PUSTAKA}

[1] A. Junaid, M. W. Tjaronge dan R. Irmawaty, "Studi Kekuatan Beton yang Menggunakan Air Laut Sebagai Air Pencampur pada Daerah Pasang Surut," Universitas Hasanuddin Makassar, Makassar, 2014.

[2] A. Kurniawandy, L. Darmayanti dan U. H. Pulungan, "Pengaruh Intrusi Air Laut, Air Gambut, Air Kelapa, dan Air Biasa terhadap Kuat Tekan Beton Normal," Jurnal Sains dan Teknologi Vol. 11, No. 2, pp. 51-58, 2012.

[3] E. Hunggurami, S. Utomo dan A. Wadu, "Pengaruh Masa Perawatan (Curing) Menggunakan Air Laut terhadap Kuat Tekan dan Absorpsi Beton," Jurnal Teknik Sipil Vol. III, No.2, pp. 103-109, 2014.

[4] Ermaitis, "Beberapa Catatan Tentang Marga Balanus (Cirripedia)," Oseana, vol. IX, no. 3, pp. 96-101, 1984.

[5] JSCE Guidelines for Concrete No. 16, Standard Spesification for Concrete Structure-2007 "Materials and Construction", Tokyo: Japan Society of Civil Engineers, 2010.

[6] P. K. Mehta, Concrete in the Marine Environment, Oxfordshire: Taylor \& Francis Books, Inc, 2003.

[7] R. Syamsuddin, A. Wicaksono dan F. F. M., "Pengaruh Air Laut pada Perawatan (Curing) Beton terhadap Kuat Tekan dan Absorpsi Beton dengan Variasi Faktor Air Semen dan Durasi Perawatan," Jurnal Rekayasa Sipil Vol. 5, No. 2, pp. 68-75, 2011.

[8] SNI 03-2834-2000, Tata Cara Pembuatan Rencana Campuran Beton Normal, Jakarta: Badan Standarisasi Nasional, 2000.

[9] SNI 03-6815-2002, Tata Cara Mengevaluasi Hasil Uji Kekuatan Beton, Jakarta: Badan Standarisasi Nasional, 2002.

[10] Wibowo, "Pengaruh Air Laut Terhadap Kuat Tekan Beton Mutu K-175," Universitas Islam 45 Bekasi, Bekasi, 2013. 